\title{
Life Cycle of Quality Management System in Organizations
}

DOI: 10.7595/management.fon.2017.0012

\begin{abstract}
Considering that some organizations implemented the ISO 9001 standard more than 25 years ago, while othersdid it a while ago, some quality management systems (QMS) are older than others. This fact led authors to question whether there are differences between long and recently implemented quality management systems. Is there a pattern that QMS follows in its aging that could be considered as a life cycle of QMS? From October 2013 to June 2014, authors have conducted a survey in 186 certified companies using structured questionnaire in order to learn whether there was a significant difference between long and recently implemented QMSs.Collected data were processed using the ANOVA test with a confidence interval of $95 \%$, i.e., $\alpha=0.05$. Results show that there is a difference between quality management systems in the mature stage and those recently implemented. However, research pointed out two facts. First,34.41\% of all surveyed companies apply QMS partially and have virtual QMS that has no purpose of improving business performances but only the purpose ofmaintaining the company's certificate. Second, in companies that apply QMS fully, the frequency of all processes (which are elements of QMS) decreases in the first seven years of implementation, while after that period it begins to increase. Also, the paper describes indicators for determining companies which partially apply QMS.
\end{abstract}

Keywords: Quality management system; process frequency; internal audit; corrective measures; preventive measures.

JEL Classification: C11, D22, L25, M11, Y10

\section{Introduction}

The implementation of quality programs or models for quality improvement, which can be based on already existing and suggested models or can be developed for particular company often leads to major change within an organization (Gokul \& Sarada, 2015; Hahn, 2012; Almaraz, 1994).Many research works, studies and surveys have been conducted on the effects of most commonly used model for quality improvement, recommended by the ISO 9001 standard, i.e.,the quality management system (QMS) model (see:Sampaioet al., 2009; Fotopouloset al, 2010; Cruciniand Kipping, 2001; Canet-Gineret al., 2010; Sroufeet al., 2008, Franceschini et al., 2016).The ISO 9001 registration efforts benefit a firm's competitiveness, but achieving the ISO 9001 certification alone will not lead to higher profitability (Pires et al., 2013; Sampaio, Saraiva\& Monteiro, 2012). However, there are studies that claim that firms reported that some specific activities and relationships did not change after a QMS adoption (Fouayziet al., 2006; Hadidi et al., 2017).

The QMS model is based on process approach (Grochau \& ten Caten, 2012; Nestic et al., 2015; Yu, To\& Lee,2012) and sees an organization as a system of processes. Therefore, it would be expected thatQMS implementation would directly affect processes of company forcing them to change.Furthermore, the logic 
conclusion indicates that processes will change as long as QMS is properly used in the company, becausecontinuous improvement isa major principle ofISO 9001.Still, the nature of changes in the organization's processes after QMS implementation is not clear. The aim of this paper is to explain what happens to QMS during its application period, from the moment the company is certified for the first time up to now.

\section{Background of research}

Goetsh and Davies (2005) indicated that the quality management system "consists of all the organization's policies, procedures, plans, resources, processes, and delineation of responsibility and authority, all deliberately aimed at achieving product or service quality levels consistent with customer satisfaction and the organization's objectives. When these policies, procedures, plans, etc., are taken together, they define how the firm works, and how quality is managed." Therefore, the QMS consists of a number of interrelated processes (Anttila \& Jussila, 2017; Domingues, Sampaio\&Arezes, 2015; Zivaljevic, Mitrovic \& Petkovic, 2013; Phenget al., 2008), all described by the QMS documentation. The QMS is actually a set of documents but when applied, quality management system consists of the organizational structure and processes necessary to implement a quality policy (Alper, 2013; Davis et al., 2012; Zelniket al., 2012).

Companies ofthe same business type,those that have the same processes, products and services, may have differently designed quality management systems. The difference originates from various approaches in designing and implementingthe QMS.It is known that the same process, depending on the designer's logic and on the required detailed level, can be designedin various ways and described differently by QMS documents. The same record, part of the QMS documentation, can have a completely different form and can require different information in two different companies. Therefore, quality management systems can be designed better or worse, can to a lower or higher degree fit the company and therefore can be more or less implemented as an integral part of the company. It is expected that those quality management systems which are designed worse or integratedless in a real business systemwill reach optimal design or become fully integratedat some point in time by using continual improvements.

An optimal quality management system conformed to ISO 9001 can be understood as an integral part of the companywhich brings benefits. Simply explained, it is a set of documents that describes processes of the company while those processes are conducted in reality exactly as they are described in documents. An optimal QMS is a system that does not live a life parallel to the real business system's life. On the contrary, a Parallel QMS is a formal system which is not implemented fully - it is set of documents which describes processes while those processesare conducted differently in reality. Therefore, it is either a burden for the companyor is periodically applied only tomaintain the certificate. After some time followingapplication, parallel systemwilleither improve to become optimal andfully adopted,or it will becompletely rejected.

The aims of ISO 9001 are to facilitate the business (De Oliveira, 2013; Psomas, Kafetzopoulos \& Fotopoulos, 2012; Baldassarreet al., 2012)and to encourage the organization's improvement (Pellicer et al., 2012). Those aims should be performed internally and externally. Internal performance should be done by optimization and standardization of processes. The standardizationreducesthe cycle time of processes (Duncan et al., 2015), thereforethe number of times of process's performance would increase perperiod i.e., process frequency would increase. External performance should be done by ensuring successful development process which would perform constantly, ensuringthat the company can keep up with changes in the environment.

The process of internal audit is one of the foundations of the ISO 9001 standard and it is usually introduced in the company for the first time along with the QMS implementation. The process of continual improvement of the QMS is based on an internal audit process, while audits identify non-conformities in the organization and collect data on the state of quality management system in order to perform a management review which directs the system towards real and possible improvements. Root causes of non-conformities are eliminated by the process of corrective actions control in order to disable reappearance of the same nonconformance.

Internal audits bring the QMS and the real operating system closer to each other and improve them together (Bernardo et al., 2012; Biasini, 2012; Karapetrovic et al., 2000; Ni et al., 2003) while the internal audit process is inseparable from the process of corrective actions control. Quantity and type of identified non-conformities in internal audit can be understood as indicators of full or partial implementation of a quality manage- 
ment system. If non-conformities relate mainly to incorrect filling of records, incorrect placing of the records or some other formal mistakes, the quality management system is either not understood as an integral part of the system or internal auditors are not doing their job properly. Since the internal auditors are part of the organization, it can be concluded that such company is using procedures and records in order to maintain certificate, or that the QMS and the real operating system are not integrated.

The process of preventive action control is conducted to eliminate any possibility of potential non-conformance appearance by applying preventive measures on the causes of possiblenonconformities. A company that fully implements the QMS understandsits business system well, therefore it is able to predict and avoid possible mistakes. As the company reduces nonconformities over time (see: Karapetrovic et al., 2006), it is expected that the number of corrective actions should decrease. Consequently, in such companies,the ratio between preventive and corrective measures would be higher than in those companies that implement the QMS partially.

It could be concluded that over the time of two systems of the QMS application, the real business system and the QMS will becomecloser until they integrate completely and continue with further changes as one inseparable system. Thismerging is impossible without changes in processes which are basic elements of both systems, the real one and the QMS. The main goal of any organization, besides surviving on market, is to develop; therefore it is expected that the process of development will become easier to conduct ,i.e., its cycle time will decrease and it would deliver more certain results. Also, it is expected that merging of business and quality management system will cause changes in the type and number of nonconformities, as well as in the ratio betweenpreventive and corrective measures.

\section{Research method}

The authors conducted a survey in 186certified companies from October 2013 to June 2014. The aim of the research was to identify whether there is a difference between long and recently implemented quality management systems and, if so,to determine the pattern that the QMS follows in its aging that can be considered as a life cycle of the QMS. The research is based on the following hypothesis:

H1: If the QMS is fully implemented, then there will be a change in the frequency of processeswhich are required by the ISO 9001 standard.

$\mathrm{H} 2$ : If the process frequency changes through time of the QMS application, the change will pass different stages which will create a life cycle of the QMS.

The research useda questionnairestructured in three parts. The first part of the questionnaire focused on general information about the company, about the methodthe company used to design and implement the QMS and about the year of its first certification. The year of the first certification indicates thecompany's QMS maturity. Also, the first part of the questionnaire contained a question which enabled the classification of companies into two groups: those companies thatintegratedthe QMS in their daily business life and those companies that have two parallel systems. This question related towhether the company applies the QMS fully, i.e., all processes are performed according to the relevant valid QMS documentation, whether the company applies some of processes according to valid QMS documents and avoids applying some, or the company applies the QMS documentation only before the external audit in order to maintain the certificate.

The second part contained questions related to thetype of documentation which the company uses to describe and control the processes required by the ISO 9001 . The same part of questionnairecontained questions about the frequency of each processthat is required by the ISO 9001 standard. The frequency of process relates to the number of the process conductions per year.Those questions were meant toindicate whether there were differences between long and recently implemented quality management systems. The processes of production or service delivery were not taken into consideration, given that company performs those processes constantly in order to survive on the market.

The third part of the questionnaire contained questions related to the number and type of nonconformities that were identified in the company by internal and external auditors, to the number of preventive and corrective measures. Those questions were to give data on the ratio between preventive and corrective measures, as well as aninsight into the company's understanding of the QMS. 
The questionnaire was sent to a management representative of each surveyed company. The sampled companies were classified into two groups according to their statement about the way they apply QMS and according to their statement about the number of internal audits a company performs per year. In casethe company did not perform at least two internal audits per year, then it will not recognize the status and importance of the processes, as well as the results of previous audits (these are important requests of the ISO 9001 standard (ISO 9001, 2014, p.73)). The first group included those companies whichimplement the QMS fully, while the second group included those which apply the QMS partially or only for maintaining certification. All companies which did not apply the QMS fully were excluded from further analysis of process frequency.

The companies which implement the QMS fully were classified according to the maturity of their quality management systems into 11 groups. Each group consisted of companies which were certified for the first time in the same year and each group of companies was processed separately. The second part of the questionnaire contained questions about the process frequency where for each process the company could answer by choosing one of 16 offered answers. For the purpose of data processing, a value between 0 and 365 was assigned to each offered answer in the questionnaire. Assigned valuesrepresent the number of the process beginnings in a single year and they are shown in Table 1.

Table 1: Assigned values for offered answers in questionnaire for process frequency

\begin{tabular}{|l|c|l|c|}
\hline \multicolumn{1}{|c|}{$\begin{array}{c}\text { Offered answer in } \\
\text { questionnaire }\end{array}$} & Assigned value & \multicolumn{1}{c|}{$\begin{array}{c}\text { Offered answer in } \\
\text { questionnaire }\end{array}$} & Assigned value \\
\hline once a day & 365 & once in eight months & 1.52 \\
\hline once a month & 12 & once in nine months & 1.35 \\
\hline once in two months & 6 & once in ten months & 1.22 \\
\hline once in three months & 4 & once in eleven months & 1.11 \\
\hline once in four months & 3 & once a year & 1 \\
\hline once in five months & 2.4 & once in two years & 0.5 \\
\hline once in six months & 2 & once in three years & 0.33 \\
\hline once in seven months & 1.4 & never & 0 \\
\hline
\end{tabular}

The frequency of processes for each group of the sample was calculated as an average of assigned valuesrelated to the answer which each company had chosen as an answer about its process frequency.Average was also used as a statistical method for processing the rest of the obtained data.In order to learn whether there was a significant difference between those eleven groups the ANOVA test was applied on the processed data with a confidence interval for of $95 \%$, i.e., $\alpha=0.05$.

\section{Research results and analysis}

The QMS is partially applied in $34.41 \%$ of all sampled companies. Those companies were excluded from further analysis. The structure of the sample according to full or partial implementation of the QMS and according to QMS age is shown in Table 2.

Table 2: The structure of the sample

\begin{tabular}{|c|c|c|c|c|c|c|c|c|c|c|c|c|c|}
\hline \multicolumn{2}{|c|}{ Age of QMS } & \multirow{2}{*}{$\begin{array}{c}\begin{array}{c}1 \\
\text { year }\end{array} \\
12\end{array}$} & \multirow{2}{*}{\begin{tabular}{|c|}
$\begin{array}{c}2 \\
\text { years }\end{array}$ \\
9 \\
\end{tabular}} & \multirow{2}{*}{\begin{tabular}{|c|}
3 \\
years \\
10 \\
\end{tabular}} & \multirow{2}{*}{$\begin{array}{c}\begin{array}{c}4 \\
\text { years }\end{array} \\
10\end{array}$} & \multirow{2}{*}{$\begin{array}{c}5 \\
\text { years } \\
12\end{array}$} & \multirow{2}{*}{$\begin{array}{c}6 \\
\text { years } \\
14\end{array}$} & \multirow{2}{*}{$\begin{array}{c}7 \\
\text { years } \\
9\end{array}$} & \multirow{2}{*}{\begin{tabular}{|c|}
$\begin{array}{c}8 \\
\text { years }\end{array}$ \\
10
\end{tabular}} & \multirow{2}{*}{$\begin{array}{c}\begin{array}{c}9 \\
\text { years }\end{array} \\
12\end{array}$} & \multirow{2}{*}{$\begin{array}{c}\begin{array}{c}10 \\
\text { years }\end{array} \\
10\end{array}$} & \multirow{2}{*}{$\begin{array}{c}>10 \\
\text { years } \\
14\end{array}$} & \multirow{2}{*}{$\begin{array}{c}\text { Total } \\
122\end{array}$} \\
\hline Companies which & [1] & & & & & & & & & & & & \\
\hline apply QMS fully & {$[\%]$} & 57.1 & 56.3 & 50.0 & 71.4 & 75.0 & 77.8 & 60.0 & 66.7 & 75.0 & 66.7 & 70.0 & 65.6 \\
\hline \multirow{2}{*}{$\begin{array}{l}\text { Companies which } \\
\text { apply QMS } \\
\text { partially }\end{array}$} & {$[1]$} & 9 & 7 & 10 & 4 & 4 & 4 & 6 & 5 & 4 & 5 & 6 & 64 \\
\hline & {$[\%]$} & 42.9 & 43.8 & 50.0 & 28.6 & 25.0 & 22.2 & 40.0 & 33.3 & 25.0 & 33.3 & 30.0 & 34.4 \\
\hline $\begin{array}{l}\text { Total No. of } \\
\text { companies in } \\
\text { maturity group }\end{array}$ & {$[1]$} & 21 & 16 & 20 & 14 & 16 & 18 & 15 & 15 & 16 & 15 & 20 & 186 \\
\hline
\end{tabular}


The minimal time of the QMS design is nine months in companies which stated to apply the QMS fully, while all of those companies usedhelp of consultants. Their reasons for the QMS implementation are different, but they all state that benefits of the QMS implementation are: better organization of work, costs reduction, higher percent of plan realization, better anticipation of customer needs, managers' better understanding of company. The average frequencies of their processes, considering the age of their QMS, are given in Table 3.

Table 3: Average frequencies of processes required by ISO 9001 depending on QMS maturity in companies that fully apply QMS

\begin{tabular}{|c|c|c|c|c|c|c|c|c|c|c|c|}
\hline Arocess & 1year & 2years & 3years & 4years & 5years & 6years & 7years & 8years & 9years & 10years & $\begin{array}{l}>10 \\
\text { years }\end{array}$ \\
\hline $\begin{array}{l}\text { Control of } \\
\text { documents }\end{array}$ & 1.242 & 2.099 & 4.351 & 4.904 & 5.337 & 9.333 & 0.266 & 0.923 & 2.630 & 3.583 & 5.865 \\
\hline $\begin{array}{l}\text { Identification of } \\
\text { custom.requirements }\end{array}$ & 27.348 & 14.853 & 14.125 & 10.904 & 7.571 & 7.390 & 7.800 & 6.540 & 7.880 & 8.667 & 12.291 \\
\hline Quality policy review & 3.388 & 3.735 & 1.423 & 0.714 & 0.786 & 0.250 & 0.766 & 0.333 & 2.300 & 0.722 & 0.291 \\
\hline $\begin{array}{l}\text { Quality objectives } \\
\text { setting }\end{array}$ & 2.583 & 2.471 & 1.131 & 1.727 & 1.857 & 1.0773 & 1.0866 & 1.500 & 1.900 & 1.682 & 2.375 \\
\hline QMS planning & 4.500 & 2.853 & 1.495 & 1.584 & 0.857 & 0.523 & 0.900 & 0.526 & 0.665 & 1.432 & 2.188 \\
\hline Management review & 5.667 & 4.176 & 1.286 & 1.571 & 1.429 & 1.750 & 1.400 & 1.250 & 1.900 & 1.300 & 7.375 \\
\hline $\begin{array}{l}\text { Human resources } \\
\text { training }\end{array}$ & 26.348 & 6.412 & 1.305 & 1.189 & 0.071 & 0.105 & 0.018 & 10.458 & 23.165 & 26.070 & 29.729 \\
\hline $\begin{array}{l}\text { Evaluating the effect. } \\
\text { of HR trainings }\end{array}$ & 8.182 & 3.912 & 1.097 & 1.119 & 0.016 & 0.073 & 0.006 & 10.273 & 23.121 & 25.333 & 28.351 \\
\hline $\begin{array}{l}\text { Identification of } \\
\text { requirem.for product }\end{array}$ & 24.167 & 3.931 & 0.282 & 1.714 & 0.143 & 0.125 & 0.866 & 2.111 & 1.210 & 1.682 & 19.988 \\
\hline $\begin{array}{l}\text { Review of requirem. } \\
\text { related to the } \\
\text { product }\end{array}$ & 23.167 & 3.206 & 0.114 & 0.357 & 0.286 & 0.273 & 0.67 & 0.523 & 0.415 & 2.403 & 18.886 \\
\hline $\begin{array}{l}\text { Customer } \\
\text { communication }\end{array}$ & 23.167 & 21.559 & 22.952 & 22.286 & 24.013 & 25.083 & 25.200 & 26.068 & 27.011 & 24.015 & 48.063 \\
\hline $\begin{array}{l}\text { Design and } \\
\text { developm. planning }\end{array}$ & 7.212 & 5.152 & 2.149 & 1.311 & 0.169 & 0.108 & 0.099 & 4.330 & 4.478 & 8.583 & 13.563 \\
\hline $\begin{array}{l}\text { Design and } \\
\text { development review }\end{array}$ & 6.737 & 2.716 & 2.649 & 1.299 & 0.584 & 0.833 & 0.900 & 4.750 & 4.500 & 6.167 & 13.590 \\
\hline $\begin{array}{l}\text { Design and } \\
\text { developm.verification }\end{array}$ & 6.598 & 2.623 & 3.013 & 1.299 & 0.357 & 0.750 & 1.100 & 4.500 & 4.665 & 6.250 & 13.660 \\
\hline $\begin{array}{l}\text { Design and } \\
\text { developm.validation }\end{array}$ & 6.432 & 1.912 & 1.448 & 1.370 & 1.941 & 0.375 & 1.140 & 2.398 & 6.315 & 6.348 & 13.125 \\
\hline $\begin{array}{l}\text { Control of design } \\
\text { and } \\
\text { developm.changes }\end{array}$ & 2.682 & 1.814 & 1.435 & 1.013 & 1.441 & 3.440 & 1.118 & 0.498 & 4.210 & 8.265 & 12.900 \\
\hline $\begin{array}{l}\text { Design and } \\
\text { devel.changes } \\
\text { review }\end{array}$ & 1.530 & 1.240 & 1.299 & 0.311 & 1.941 & 0.750 & 0.436 & 0.333 & 1.330 & 10.182 & 11.438 \\
\hline Purchasing & 276.120 & 69.176 & 68.988 & 61.156 & 54.571 & 52.023 & 39.200 & 53.023 & 53.045 & 53.515 & 199.125 \\
\hline $\begin{array}{l}\text { Verification of } \\
\text { purchased product }\end{array}$ & 259.167 & 77.941 & 64.441 & 64.013 & 66.857 & 44.770 & 39.999 & 62.25 & 62.545 & 62.265 & 243.488 \\
\hline $\begin{array}{l}\text { Control of monitoring } \\
\text { and measuring equi. }\end{array}$ & 7.417 & 1.854 & 0.429 & 2.026 & 0.156 & 0.375 & 0.400 & 1.300 & 2.430 & 8.722 & 15.910 \\
\hline $\begin{array}{l}\text { Monitoring \& } \\
\text { measuring cust.satis. }\end{array}$ & 16.167 & 14.882 & 5.649 & 3.857 & 2.013 & 0.750 & 0.532 & 3.068 & 1.665 & 2.320 & 17.875 \\
\hline $\begin{array}{l}\text { Monitoring \& meas. } \\
\text { processes quality }\end{array}$ & 19.167 & 12.471 & 8.305 & 12.429 & 12.143 & 10.500 & 10.600 & 10.887 & 13.500 & 14.555 & 24.375 \\
\hline $\begin{array}{l}\text { Monitoring \& meas. } \\
\text { product quality }\end{array}$ & 61.182 & 59.957 & 57.370 & 48.740 & 48.286 & 34.150 & 29.932 & 31.645 & 48.045 & 49.515 & 53.938 \\
\hline Internal audit control & 5.250 & 5.941 & 3.143 & 3.214 & 3.857 & 3.500 & 3.340 & 3.750 & 3.500 & 3.750 & 4.938 \\
\hline $\begin{array}{l}\text { Corrective action } \\
\text { control }\end{array}$ & 14.033 & 14.188 & 11.107 & 10.514 & 8.76 & 7.867 & 6.947 & 4.191 & 4.143 & 4.182 & 3.700 \\
\hline $\begin{array}{l}\text { Preventive action } \\
\text { control }\end{array}$ & 1.917 & 1.059 & 1.1407 & 1.233 & 1.3538 & 1.167 & 1.286 & 4.333 & 5.375 & 7.5 & 12.188 \\
\hline $\begin{array}{l}\text { FREQUENCY OF } \\
\text { ALL PROCESSES }\end{array}$ & 841.37 & 342.133 & 282.127 & 261.854 & 246.796 & 207.341 & 176.008 & 251.761 & 311.943 & 349.008 & 829.215 \\
\hline
\end{tabular}


As the aim of research was to find out whether there is any difference between eleven groups of companies, i.e.,whether the QMS maturity influences the frequency of processes, the ANOVA method was applied with confidence interval of $95 \%$, i.e., $\alpha=0.05$, andthe F-test was used.The results of the ANOVA are given in Table 4.

Table 4: Results of ANOVA

\begin{tabular}{|c|c|c|}
\hline Number of groups & $\mathrm{k}$ & 11 \\
\hline Number of data in one group & $\mathrm{n}$ & 26 \\
\hline Number of data in all groups & $\mathrm{N}=\mathrm{k} * \mathrm{n}$ & 286 \\
\hline Intergroup variability degree of freedom & $\mathrm{k}-1$ & 10 \\
\hline Internal variability degree of freedom & N-k & 275 \\
\hline Total Average & $\bar{X}_{\mathrm{t}}=\sum_{j=1}^{11} \sum^{26} X_{i j} / N$ & 14.33410629 \\
\hline Internal variability & $\sum_{i=1}^{11}\left(\sum_{j=1}^{26}\left(X_{i}-X_{i j}\right)^{2}\right)$ & 275708.99781 \\
\hline Intergroup variability & $\sum_{i=1}^{11}\left(\overline{X_{i}}-X_{t}\right)^{2} * n$ & 21163.26061 \\
\hline Variance of intergroup variability & $\underset{i=1}{\sigma_{g}{ }^{2}}=\sum^{11}\left(\overline{X_{i}}-\bar{X}_{t}\right)^{2} * n /(k-1)$ & 2116.326061 \\
\hline Variance of internal variability & $\sigma_{i=1}^{2}=\sum_{j=1}^{11}\left(\sum^{26}\left(\bar{X}_{i}-X_{i j}\right)^{2}\right) / N-k$ & 1002.578174 \\
\hline F value for sample & $F=\sigma_{g}^{2} / \sigma_{i}^{2}$ & 2.110883836 \\
\hline
\end{tabular}

As variance quotation is higher than statistics $F(10 ; 275 ; 0,05)=1.865224851$, it can be concluded that there is a difference between different groups of QMS maturity, meaning that QMS maturity influences frequency of processes in the company.

Figure 1 shows the trend in change of processes frequency over the QMS ageing. At the beginning of QMS implementation, everything seemed to be slowing, due to the fact that the frequency of all processes is decreasing. One assumption could be that cause of frequency decreasinglies in the company's tendency to conform newly implemented QMS to the real operating system. At the beginning of QMS implementation all procedures could be designed to fit ideal process flows, but those ideal flows could be far away from reality. Therefore QMS procedures and processes in reality are changing together, trying to meet each other in the optimum.

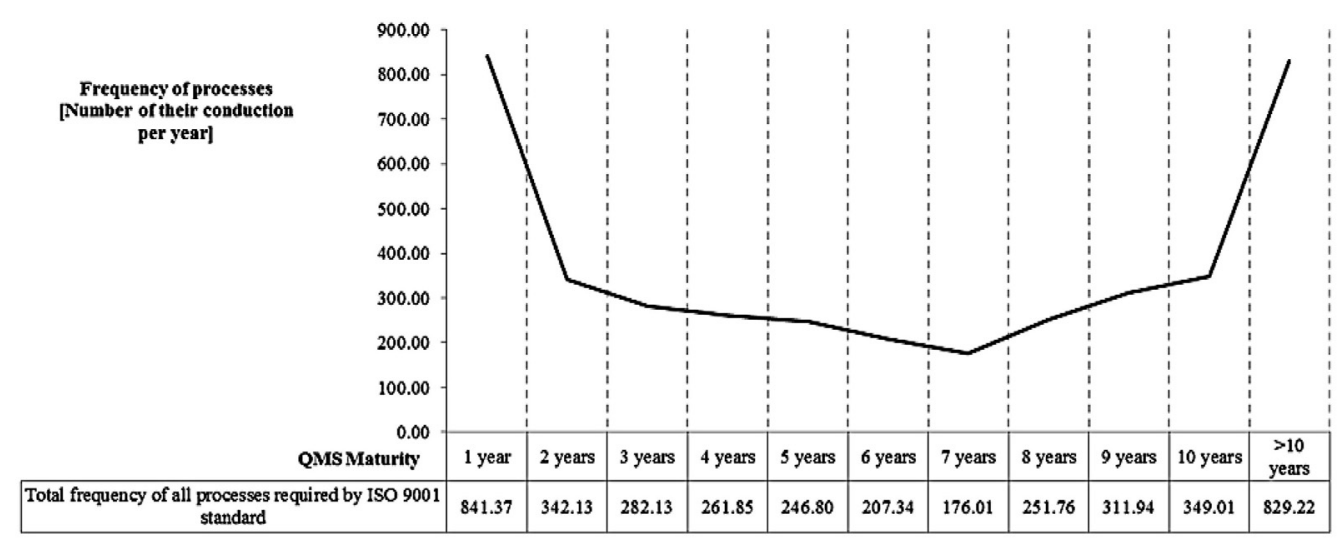

Figure 1: Change of frequency of all company's processes depending on QMS maturity

After the implementation, changes of the QMS should be done by conducting a process of "control of documents". Figure 2 shows a trend of frequency of "control of documents" process depending on QMS maturity. It is obvious that the frequency of all processes has an opposite trend regarding the frequency of "control of documents" until the sixth year of the QMS application. This supports the assumption that the firm is finding the way to conform processes in reality and QMS procedures. This fitting should not be taken as a real improvement of both systems: the QMS and the business system. 


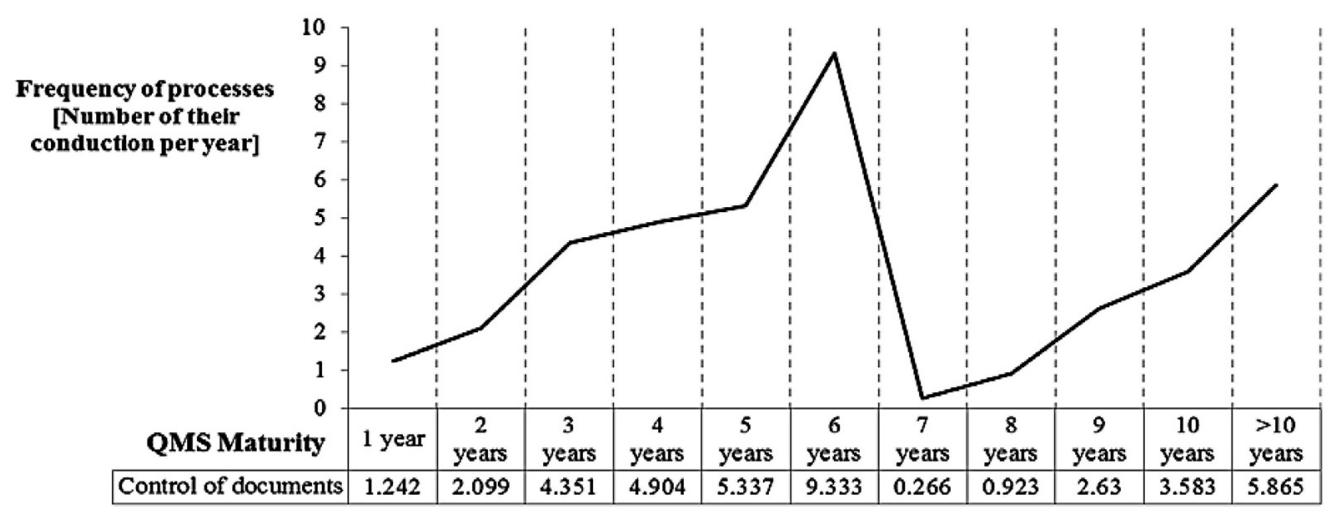

Figure 2: Change of frequency of process "control of documents" depending on QMS maturity

In the seventh year of QMS application, the frequency of "control of documents" process rapidly decreases indicating that the company has conformedits QMS to the business system, therefore processes described by procedures are conducted as they are designed. As there is no need any more for conformingthe QMS to business system, the process of change almost stops. A concurrent increase in frequency of all processes and of the process of "control of documents" begins after the seventh year of QMS application. This can be explained by the fact that the business system andthe QMS integrated, causing the procedures improvement to be simultaneously adopted in reality after the seventh year.

Figure 3 shows changes in the frequency ofthe "design and development" process. The frequency of the "design and development" process decreases with the ageing of the QMS, but after seven years of its maturity, the frequency of the "design and development" process begins to increase. Compared to the life cycle of an organization, the frequency of the "design and development" process behaves in an opposite manner. It seems that in the first seven years the company focuses all its efforts on internal changes, but after that period it turns to external environment.

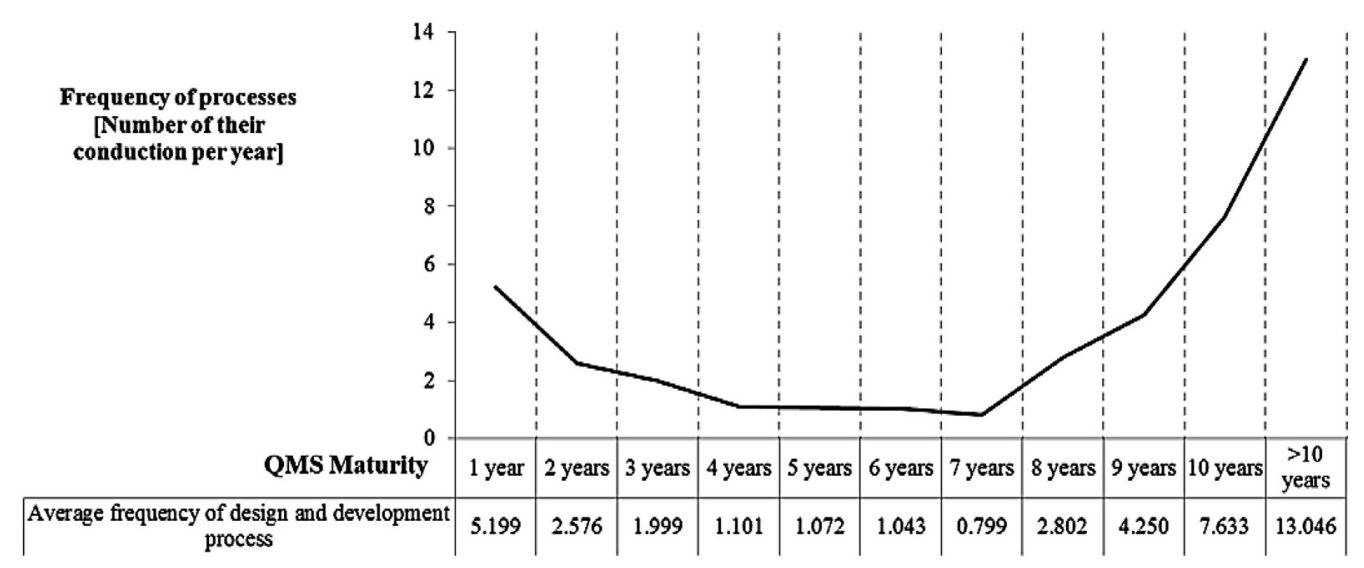

Figure 3: Change of frequency of process "design and development" depending on QMS maturity

The frequency of corrective and preventive actions, shown in Figure 4, ischanging in time with the QMS aging, too. The relation between corrective and preventive actions declines with the QMS ageing which indicates that the company is more anticipant over time, while it acquires the ability to prevent adverse eventsand understands the QMS is better over time. 


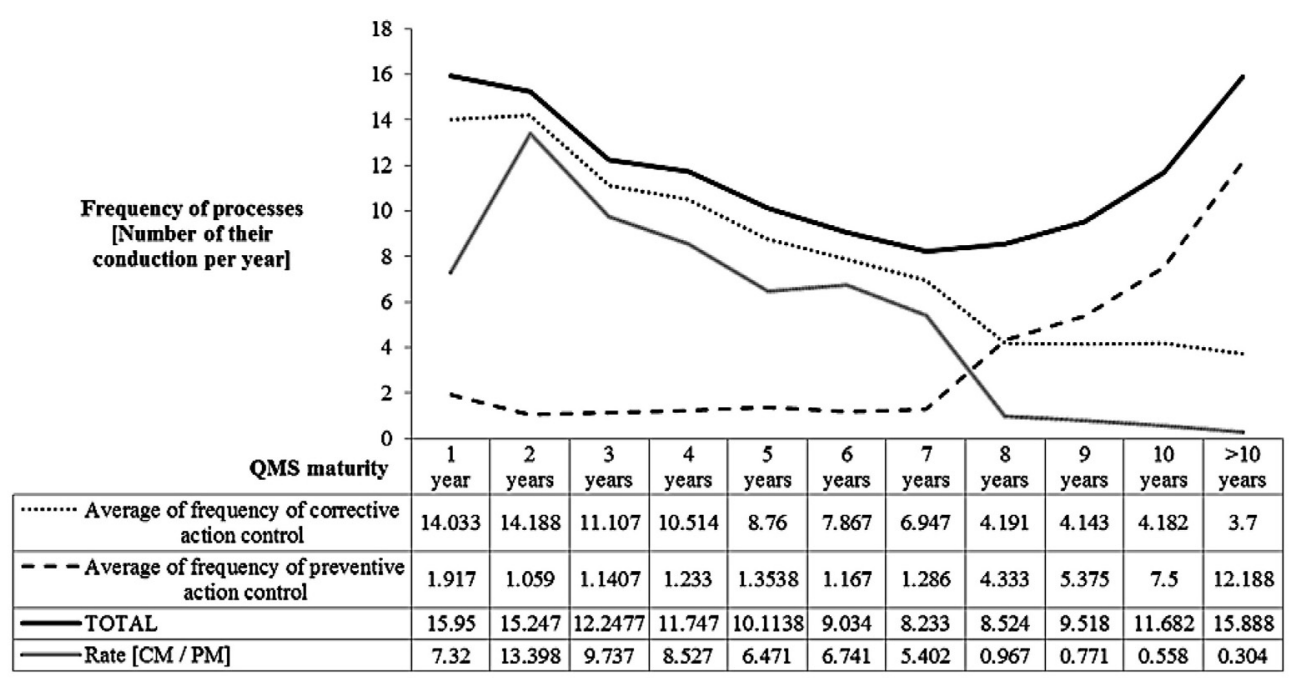

Figure 4: Change in quantity of corrective and preventive measures depending on QMS maturity

The number of nonconformities identified during the internal audit decreases with the ageing of the QMSand the share of nonconformities related to the formal mistakes that do not offer the potential forsubstantial QMS and business improvement is being reduced (Figure 5). It further means thatinternal audits are conducted better and thatmore attention is paid to the substantial improvements of QMS in time.

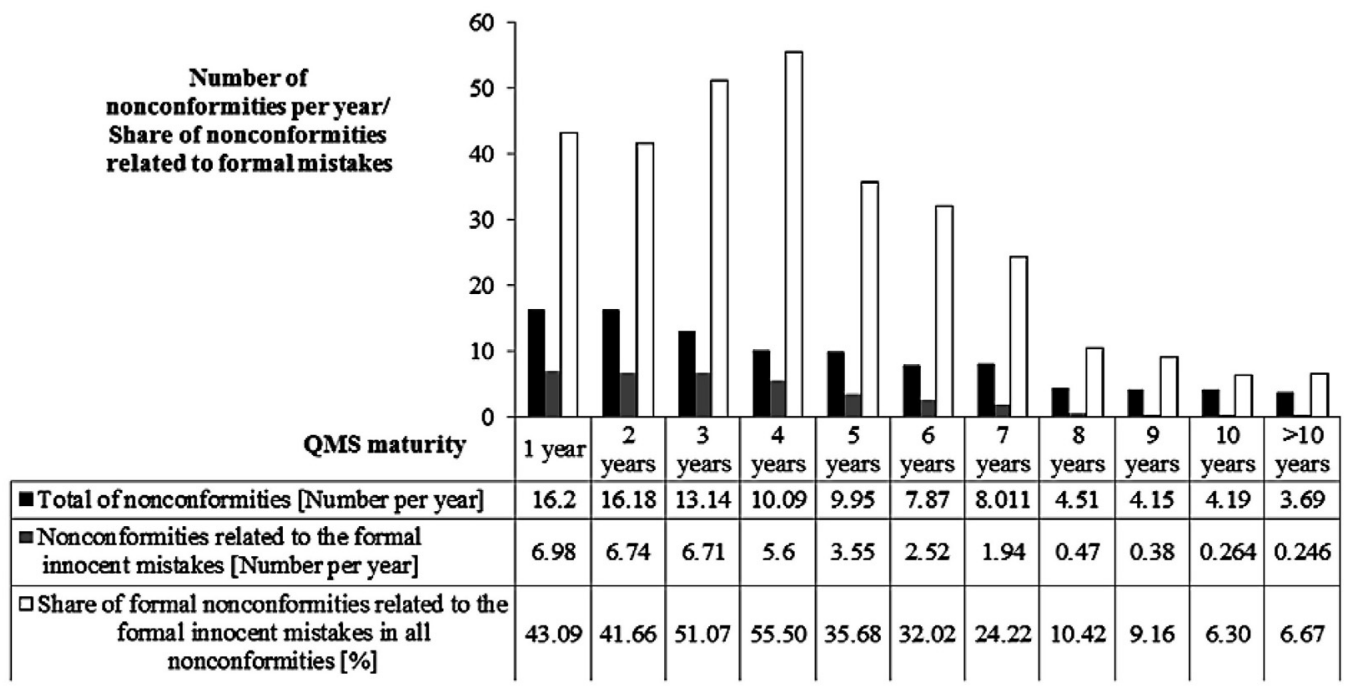

Figure 5: Change in number and type of nonconformities depending on QMS maturity

Table 5 shows a year of maximal and minimal frequencies of each process, together withthe change rate which representsa quotient of the maximum and minimum frequencies of the same process. As the rate is higher, the change is larger. 
Table 5: Minimal and maximal frequencies and change rate

\begin{tabular}{|c|c|c|c|c|c|c|}
\hline & \begin{tabular}{|c|} 
Maximal \\
frequency of \\
process \\
change
\end{tabular} & $\begin{array}{c}\text { Year of QMS } \\
\text { maturity with } \\
\text { maximal process } \\
\text { frequency }\end{array}$ & $\begin{array}{l}\text { Minimal } \\
\text { frequency of } \\
\text { process } \\
\text { change }\end{array}$ & $\begin{array}{c}\text { Year of QMS } \\
\text { maturity with } \\
\text { minimal process } \\
\text { frequency }\end{array}$ & $\begin{array}{l}\text { Difference } \\
\text { between } \\
\text { maximal and } \\
\text { minimal } \\
\text { frequency }\end{array}$ & $\begin{array}{c}\text { Change rate } \\
\operatorname{Max} / \text { Min }\end{array}$ \\
\hline $\begin{array}{l}\text { Evaluating the effectiveness of } \\
\text { the human resource trainings }\end{array}$ & 28.351 & after $10^{\text {th }}$ year & 0.006 & $7^{\text {th }}$ year & 28.345 & 4725.167 \\
\hline Human resources training & 29.729 & after $10^{\text {th }}$ year & 0.018 & $7^{\text {th }}$ year & 29.711 & 1651.611 \\
\hline $\begin{array}{c}\text { Review of requirements related } \\
\text { to the product } \\
\end{array}$ & 23.167 & $1^{\text {st }}$ year & 0.114 & $3^{\text {rd }}$ year & 23.053 & 203.2193 \\
\hline $\begin{array}{l}\text { Identification of requirements } \\
\text { related to the product }\end{array}$ & 24.167 & $1^{\text {st }}$ year & 0.125 & $6^{\text {th }}$ year & 24.042 & 193.336 \\
\hline $\begin{array}{c}\text { Design and development } \\
\text { planning }\end{array}$ & 13.563 & after $10^{\text {th }}$ year & 0.099 & $7^{\text {th }}$ year & 13.464 & 137 \\
\hline $\begin{array}{c}\text { Control of monitoring and } \\
\text { measuring equipment }\end{array}$ & 15.91 & after $10^{\text {th }}$ year & 0.156 & $5^{\text {th }}$ year & 15.754 & 101.9872 \\
\hline $\begin{array}{c}\text { Design and development } \\
\text { verification }\end{array}$ & 13.66 & after $10^{\text {th }}$ year & 0.357 & $5^{\text {th }}$ year & 13.303 & 38.26331 \\
\hline $\begin{array}{l}\text { Design and development } \\
\text { changes review }\end{array}$ & 11.438 & after $10^{\text {th }}$ year & 0.311 & $4^{\text {th }}$ year & 11.127 & 36.77814 \\
\hline Control of documents & 9.333 & $6^{\text {th }}$ year & 0.266 & $7^{\text {th }}$ year & 9.067 & 35.08647 \\
\hline $\begin{array}{l}\text { Design and development } \\
\text { validation }\end{array}$ & 13.125 & after $10^{\text {th }}$ year & 0.375 & $6^{\text {th }}$ year & 12.75 & 35 \\
\hline $\begin{array}{l}\text { Monitoring and measuring } \\
\text { customer satisfaction }\end{array}$ & 17.875 & after $10^{\text {th }}$ year & 0.532 & $7^{\text {th }}$ year & 17.343 & 33.59962 \\
\hline $\begin{array}{l}\text { Control of design and } \\
\text { development changes }\end{array}$ & 12.9 & after $10^{\text {th }}$ year & 0.498 & $8^{\text {th }}$ year & 12.402 & 25.90361 \\
\hline $\begin{array}{c}\text { Design and development } \\
\text { review }\end{array}$ & 13.59 & after $10^{\text {th }}$ year & 0.584 & $5^{\text {th }}$ year & 13.006 & 23.27055 \\
\hline Quality policy review & 3.735 & $2^{\text {nd }}$ year & 0.25 & $6^{\text {th }}$ year & 3.485 & 14.94 \\
\hline Preventive action control & 12.188 & after $10^{\text {th }}$ year & 1.059 & $1^{\text {st }}$ year & 11.129 & 11.50897 \\
\hline QMS planning & 4.5 & $1^{\text {st }}$ year & 0.523 & $6^{\text {th }}$ year & 3.977 & 8.604207 \\
\hline Purchasing & 276.12 & $1^{\text {st }}$ year & 39.2 & $7^{\text {th }}$ year & 236.92 & 7.043878 \\
\hline $\begin{array}{l}\text { Verification of purchased } \\
\text { product }\end{array}$ & 259.167 & $1^{\text {st }}$ year & 39.999 & $7^{\text {th }}$ year & 219.168 & 6.479337 \\
\hline Management review & 7.375 & after $10^{\text {th }}$ year & 1.25 & $8^{\text {th }}$ year & 6.125 & 5.9 \\
\hline $\begin{array}{l}\text { Identification of customer } \\
\text { requirements }\end{array}$ & 27.348 & $1^{\text {st }}$ year & 6.54 & $8^{\text {th }}$ year & 20.808 & 4.181651 \\
\hline Corrective action control & 14.188 & $2^{\text {nd }}$ year & 3.7 & after $10^{\text {th }}$ year & 10.488 & 3.834595 \\
\hline $\begin{array}{c}\text { Monitoring and measuring } \\
\text { processes quality }\end{array}$ & 24.375 & after $10^{\text {th }}$ year & 8.305 & $3^{\text {rd }}$ year & 16.07 & 2.934979 \\
\hline Quality objectives setting & 2.583 & $1^{\text {st }}$ year & 1.0773 & $6^{\text {th }}$ year & 1.5057 & 2.397661 \\
\hline Customer communication & 48.063 & after $10^{\text {th }}$ year & 21.559 & $2^{\text {nd }}$ year & 26.504 & 2.229371 \\
\hline $\begin{array}{l}\text { Monitoring and measuring } \\
\text { product quality }\end{array}$ & 61.182 & $1^{\text {st }}$ year & 29.932 & $7^{\text {th }}$ year & 31.25 & 2.044033 \\
\hline \multirow[t]{3}{*}{ Internal audit control } & 5.941 & $2^{\text {nd }}$ year & 3.143 & $3^{\text {rd }}$ year & 2.798 & 1.890232 \\
\hline & $\begin{array}{l}\text { Average } \\
\text { maximum }\end{array}$ & $\begin{array}{c}\text { Maximal process } \\
\text { frequency mostly } \\
\text { appeared }\end{array}$ & $\begin{array}{l}\text { Average } \\
\text { minimum }\end{array}$ & $\begin{array}{c}\text { Minimal process } \\
\text { frequency mostly } \\
\text { appeared in }\end{array}$ & $\begin{array}{l}\text { Average } \\
\text { difference }\end{array}$ & $\begin{array}{l}\text { Average } \\
\text { rate }\end{array}$ \\
\hline & 37.445 & after $10^{\text {th }}$ year & 6.153 & $7^{\text {th }}$ year & 31.292 & 281.316 \\
\hline
\end{tabular}

The largest change in the process frequency occurs in two processes: in evaluating the effectiveness of the human resource trainings and in conducting human resource trainings. The data in Table 3 show thata rapid increase in frequencies of those two processes starts after seven years of QMS application. Before the seventh year the frequency decreases.

The seventh year of QMS application is obviously a critical year;most processes have a minimal frequency in this year. Furthermore,the number of corrective actions is larger than the number of preventive actions for the last time in the seventh year. 
It can be concluded that the QMS life cycle consists of two stages: the fitting stage and the beneficial stage. The fitting stage, characterized by the company's tendency to conform the QMS to the real business system, lasts for seven years. In this stage, theprocess of development is slowing, the frequency of all changes in processes is constantly increasing and corrective activities are much more frequent than preventive ones. The company learns how to use the QMS and how to benefit from it. Nonconformities are frequent and the company is fixing the already occurred errors. In time, the company understands the QMS better, therefore the number of formal nonconformities is reduced, and the company begins to engage in substantive improvements.

A beneficial stage occurs after seven years of QMS application if the company did not reject its QMS. It is expected in this period that development process constantly increases its frequency, while changes in the QMS documentation starta new cycle of change. Preventive actions are more frequent than corrective; the company anticipates adverse events and threats, tending to eliminate them before errors occur. Almost all nonconformities are substantial but their occurrence is low. Everything in the company wakes, all processes accelerate and the company finally starts to benefit from the QMS implementation.

Nonconformities are related to the formal mistakes in $96.875 \%$ of companieswith a parallel QMS and nonconformitiesare identified only by internal audits. In $100 \%$ of those companies customer complaints neverinitiate corrective actions and usually are not recorded anywhere. Therefore, companies with a parallel QMS are not able to analyze the results of complaints resolutions. In $93.75 \%$ of these companies internal audits have been conducted only once per year, a QMS has been designed for three to four months by a consultant who is usually (in 68.75\%) still maintaining a QMS and conducting internal audits in the company. Most of those companies (84.375\%) claimed in the survey that the major problem in their QMS is that procedures and records were too complicated or that the QMS documentation did not describe real processes. Those companies have parallel QMS systemswhichare pulling them downhill. It is obvious that consultants play an important roleindesigning successful quality management systems and influence the future development of the QMS and its integration into the business system. Also, companies' attitude towards the importance of the QMS and its improvement depend on consultants (Cruciniand Kipping, 2001).

\section{Conslusion}

The research has shown that quality management systems have a life cycle each which consists of two stages -each characterized by different trends in frequency of process required bythe ISO 9001 standard, the development process, of preventive and of corrective actions. Given that the development process has the least frequency aroundthe seventh year after the QMS implementation, its flow should be recognized as the most important. In the same year of the QMS age number of corrective actions is larger than the number of preventive actions per year for the last time, while the share of substantial nonconformities identified during internal audits rapidly grows. Considering all previously elaborated,the seventh year afterthe QMS implementation is a critical period for those companies whichtend to use the QMS fully in order to improvetheirperformances.

The research has also shown that companies with a parallel QMS can be identified by following indicators: most of nonconformities relate to the formal mistakes; all nonconformities are identified only by internal audit; customer complaints never initiate corrective actions; QMS was designed for three to four months before by a consultant who is usually still maintaining it; procedures and records are too complicated. Therefore, for companies with parallel QMS the only way for making things better is to start designing the QMS from the beginning.

Finally, the esearch shows that the maturity of the quality management system affects the frequency of all processes in companies that apply the QMS fully. It is expected for frequency of all processes to decline in the first seven years, while the frequency of "control of documents" process increases during that time. A reverse phenomenon will occur in the next five years of application. Also, it is expected that a certain percentage of all QMS is deliberately parallel. As companies with parallel QMS continuously keep their certificates (see: Finkle \& Shin, 2007), external auditors should be either better trained or more objective and brave in makingdecisionsabouttaking away certificates from companies with a parallel QMS. 


\section{REFERENCES}

[1] Almaraz, J.(1994). Quality management and the process of change.Journal of Organizational Change Management, 7(2),6-14.DOI:10.1108/09534819410056096

[2] Alper, M. M. (2013). Experience with ISO quality control in assisted reproductive technology. Fertility and sterility, 100(6), 1503-1508.DOI:10.1016/j.fertnstert.2013.08.055

[3] Anttila, J., \& Jussila, K. (2017). ISO 9001: 2015-a questionable reform. What should the implementing organisations understand and do?.Total Quality Management \& Business Excellence, 116.DOI:10.1080/14783363.2017.1309119

[4] Baldassarre, M. T., Caivano, D., Pino, F. J., Piattini, M., \&Visaggio, G. (2012). Harmonization of ISO/IEC 9001: 2000 and CMMI-DEV: from a theoretical comparison to a real case application. Software Quality Journal, 20(2), 309-335.

[5] Bernardo, M., Casadesus, M., Karapetrovic, S., \& Heras, I. (2012). Do integration difficulties influence management system integration levels?.Journal of Cleaner Production, 21(1), 23-33.DOI:10.1016/j.jclepro.2011.09.008

[6] Biasini, V. (2012). Implementation of a quality management system in a public research centre. Accreditation and Quality Assurance, 17(6), 621-626.

[7] Canet-Giner M.T., Fernández-Guerrero R. \&Peris-Ortiz M. (2010). Changing the strategy formation process in a service cooperative.Journal of Organizational Change Management, 23(4),435 452.DOI:10.1108/09534811011055412

[8] Crucini, C.\& Kipping M. (2001).Management consultancies as global change agents? Evidence from Italy.Journal of Organizational Change Management, 14(6), 570 - 589.DOI:10.1108/EUM0000000006143

[9] Davis, E., Hampson, K., Bray, C., Dixon, K., Ollier, W., \&Yuille, M. (2012). Selection and implementation of the ISO9001 standard to support biobanking research infrastructure development. Biopreservation and biobanking, 10(2), 162-167.DOI:10.1089/bio.2011.0044

[10] De Oliveira, O. J. (2013). Guidelines for the integration of certifiable management systems in industrial companies. Journal of Cleaner Production, 57, 124-133.DOI:10.1016/j.jclepro.2013.06.037

[11] Domingues, J. P. T., Sampaio, P., \&Arezes, P. M. (2015). Analysis of integrated management systems from various perspectives. Total Quality Management \& Business Excellence, 26(11-12), 13111334.DOI:10.1080/14783363.2014.931064

[12] Duncan, W., Bottenberg, M., Chase, M., Chesnut, R., Clarke, C., Schott, K., Torry, R., \& Welty, T. (2015). An industrial engineering approach to cost containment of pharmacy education. American Journal of Pharmaceutical Education, 79(9), 131-137.DOI:10.5688/ajpe799131

[13] Finkle, A., \& Shin, D. (2007). Conducting inaccurate audits to commit to the audit policy. International Journal of Industrial Organization, 25(2), 379-389. DOI:10.1016/j.ijindorg.2006.05.005

[14] Fotopoulos C.V., Psomas E.L.\&VouzasF.K. (2010). Investigating total quality management practice's inter-relationships in ISO 9001:2000 certified organisations.Total Quality Management and Business Excellence, 21(5),503 - 515.DOI:10.1080/14783363.2010.481512

[15] Fouayzi, H., Caswell, J. A.\& Hooker, N. H. (2006). Motivations of fresh-cut produce firms to implement quality management systems.Applied Economic Perspectives and Policy, 28(1),132146.DOI:10.1111/j.1467-9353.2006.00277.x

[16] Franceschini, F., Galetto, M., \& Mastrogiacomo, L. (2016). ISO 9001 certification and failure risk: any relationship?.Total Quality Management \& Business Excellence, 115.DOI:10.1080/14783363.2016.1253466

[17] Goetsh, D.\& Davis, D. (2005).Understanding and Implementing ISO 9000: 2000.Englewood Cliffs, NJ: Prentice Hill.

[18] Gokul, C. M., \&Sarada, K. (2015). AC optimal power flow calculation for Locational Marginal Pricing. Indian Journal of Science and Technology, 8(17), 1.DOI: 10.17485/ijst/2015/v8i17/70092

[19] Grochau, I. H., \& ten Caten, C. S. (2012). A process approach to ISO/IEC 17025 in the implementation of a quality management system in testing laboratories. Accreditation and Quality Assurance, 17(5), 519-527.

[20] Hadidi, L., Assaf, S., Aluwfi, K., \& Akrawi, H. (2017). The effect of ISO 9001 implementation on the customer satisfaction of the engineering design services. International Journal of Building Pathology and Adaptation, (just-accepted), 00-00.DOI:10.1108/IJBPA-01-2017-0004

[21] Hahn, R. (2012). Standardizing social responsibility? New perspectives on guidance documents and management system standards for sustainable development. IEEE Transactions on Engineering Management, 59(4), 717-727. DOI: 10.1109/TEM.2012.2183639 
[22] ISO, 2014. ISO/DIS 9001, Quality management systems - Requirements, Geneva: International Organization for Standardization.

[23] Karapetrovic, S., Casadesús, M. \& Heras, I. (2006). Dynamics and Integration of Standardized Management Systems.DocumentaUniversitariaSerieGitaspNo. 1, Girona, Spain.

[24] Karapetrovic S.\&Willborn W. (2000). Generic audit of management systems: fundamentals.Managerial Auditing Journal, 5(6),279 - 294.DOI:10.1108/02686900010344287

[25] Nestic, S., Stefanovic, M., Djordjevic, A., Arsovski, S., \&Tadic, D. (2015). A model of the assessment and optimisation of production process quality using the fuzzy sets and genetic algorithm approach. European Journal of Industrial Engineering, 9(1), 77-99.DOI:10.1504/EJIE.2015.067453

[26] Ni Z.\&Karapetrovic S. (2003). Perennial self-audit: model and applications.Managerial Auditing Journal, 18(5), 363 - 373.DOI:0.1108/02686900010344287

[27] Pellicer, E., Correa, C. L., Yepes, V., \&Alarcón, L. F. (2012). Organizational improvement through standardization of the innovation process in construction firms. Engineering Management Journal, 24(2), 40-53.DOI:10.1080/10429247.2012.11431935

[28] Pheng, L. S.\&Hou, C. W. (2008). Middle management's influence on the effectiveness of ISO 9000 Quality Management Systems in Architectural Firms. Architectural Engineering and Design Management, 4(3-4), 189-205.

[29] Pires, A. R., Cociorva, A., Saraiva, M., Novas, J. C., \& Rosa, Á. (2013). Management of quality-related costs. The case of Portuguese companies. Total Quality Management \& Business Excellence, 24(7-8), 782-796.DOI:10.1080/14783363.2013.792993

[30] Psomas, E. L., Kafetzopoulos, D. P., \& Fotopoulos, C. V. (2012). Developing and validating a measurement instrument of ISO 9001 effectiveness in food manufacturing SMEs. Journal of Manufacturing Technology Management, 24(1), 52-77.DOI:10.1108/17410381311287481

[31] Sampaio, P., Saraiva, P., \& Monteiro, A. (2012). ISO 9001 certification pay-off: myth versus reality. International Journal of Quality \& Reliability Management, 29(8), 891-914.DOI:10.1108/02656711211270351

[32] Sampaio P., Saraiva P. \& Rodrigues A. G. (2009). An analysis of ISO 9000 data in the world and the European Union.Total Quality Management and Business Excellence, 20(12),13031320.DOI:10.1080/14783360903250597

[33] Sroufe R. \& CurkovicS. (2008). An examination of ISO 9000:2000 and supply chain quality assurance.Journal of Operations Management, 26, 503-520 DOI:10.1016/j.jom.2007.06.006

[34] Yu, B. T., To, W. M., \& Lee, P. K. (2012). Quality management framework for public management decision making. Management Decision, 50(3), 420-438.DOI:10.1108/00251741211216214

[35] Zelnik, M., Maletic, M., Maletic, D., \&Gomiscek, B. (2012). Quality management systems as a link between management and employees. Total Quality Management \& Business Excellence, 23(1), 4562.DOI:10.1080/14783363.2011.637781

[36] Zivaljevic, A., Mitrovic, Z.,\& Petkovic, M. (2013). Conceptual and mathematical model for quality improvement in health care. The Service Industries Journal, 33(5), 516541.DOI:10.1080/02642069.2011.622368

Received: 2016-01-29

Accepted: 2017-10-23 


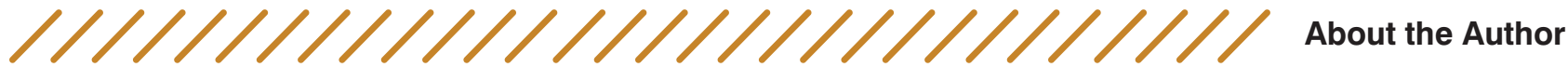

Aleksandra Živaljević azivaljevic@naisbitt.edu.rs

Aleksandra Živaljević is an assistant professor at the Faculty of Business Studies, John Naisbitt University, where she teaches courses in Quality Management, Operations Management and Logistics at the undergraduate level and Management of R\&D and Quality Management in Health Care at graduate academic level of studies. She was a Vice-Dean for scientific research of the Faculty of Business Studies and Quality Manager

of John Naisbitt University. She is the president of the Commission for impartiality assurance of certification body, 'Management Systems Certification'. She holds a PhD from the Department of Quality Management at the Faculty of Organizational Sciences in Belgrade. Her academic career is devoted to the study of quality management and operations management in specific organizations and systems - education and health care. She has published more than 30 scientific papers, some of those in SCI journals.

Vuk Bevanda vbevanda@naisbitt.edu.rs

Vuk Bevanda is an assistant professor at the Faculty of Business Studies, John Naisbitt University. He has published a number of papers in various categories, including the best-ranked national and international conferences, journals, and thematic collections of papers. He also published a textbook and a practicum of Microeconomics. He has lectured at the Chamber of Commerce, was the chairman of the scientific conference at the John Naisbitt University, a member of the program committee of the regional conference.

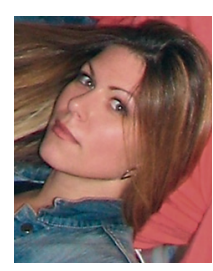

Dragana Trifunović dtrifunovic@naisbitt.edu.rs

Dragana Trifunović is an assistant professor at the Faculty of Business Studies , John Naisbitt University, where she teaches courses in Management of research and development and Technology management. She is a vice dean for the first level studiesat the Faculty of Business Studies. She has published a number of papers in various categories, including national and international conferences, journals, and

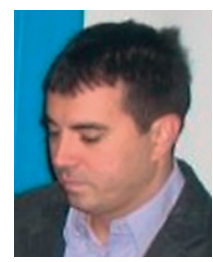
thematic collections of papers. 